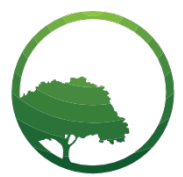

Research in Business \& Social Science

IJRBS VOL 8 NO 5 ISSN: 2147-4478

\title{
The role of stakeholders in managing order and sanitation of Sukaramai traditional market
}

\author{
Hanif Arinda ${ }^{a^{*}}$, Fikarwin Zuska ${ }^{b}, Z_{\text {Zlkifli Lubis }}^{c}$ \\ ${ }^{a}$ Master of Development Studies, Universitas Sumatera Utara, Medan, Indonesia \\ ${ }^{b, c}$ Department of Anthropology, Universitas Sumatera Utara, Medan, Indonesia
}

Crossref

\begin{tabular}{l} 
A R T I C L E I N F O \\
\hline Article history: \\
Received 29 July 19 \\
Received in revs. form 15 August 19 \\
Accepted 18 August 19 \\
\hline Keywords: \\
Shareholder \\
Order \\
Sanitation \\
Traditional Market \\
JEL Classification: \\
015 \\
Q56
\end{tabular}

\begin{abstract}
A B S T R A C T
A traditional market is a place where people's economic, social, and cultural activities occur. In Indonesia, the traditional market is known as the place which is, disorganized, dingy, stink, and disordered, but it is still favored by many people in meeting their daily needs. The objective of this study was to find out the role of stakeholders in managing the order and sanitation Sukaramai traditional market. The study used a descriptive qualitative method. The data were gathered by conducting interviews with some informants, consisted of Regional Government of Medan Market, Urban Civil Service Police, Sanitation Department of Medan, vendors, and buyers. The result of the research showed that the stakeholders had worked according to the Regional Regulation on the Management of order and sanitation of Sukaramai traditional market. However, the Sanitation Agency could not do its job well even though waste management in this market was not optimal. Vendors disobedience with the rules was also the cause of why this market could not be operated cleanly and neatly.
\end{abstract}

\section{Introduction}

Traditional market is a public place where buyers and vendors do transaction and bargaining activities directly (Prastyawan \& Isbandono, 2018). The goods which are sold and bought are usually goods which are needed daily and easily found and still become the people's choice for fulfilling their daily needs. This place is the one which is very strategic and advantageous for retailers since people can get inexpensive goods and do bargaining system with the vendors. Today, however, traditional markets in Indonesia are not able to compete with modern markets (Febrianty, 2013) (Nelwan, Lapian, \& Rumokoy, 2017). It seems that more and more people go the modern market for shopping even though some of them still choose traditional markets.

A traditional market is often identified with filthy, muddy, stink, unorganized, and disordered. Thus might be the cause why it cannot compete with a modern market. Even though the goods offered in a modern market are more expensive than those in a traditional market, people tend to choose modern market to go shopping since a modern market is cleaner, not muddy, and the goods are more hygienic, and neat. This difference can be seen from the research conducted by Natawidjaja where the sale in modern markets increases $15 \%$ per year, while the sale in traditional markets decreases $2 \%$ per year (Tanuwidjaja \& Wirawan, 2012).

One of the traditional markets which was studied in this research was Sukaramai traditional market in Medan, North Sumatera. In this traditional market, the vendors use pavement and sidewalk to sell their merchandise. Therefore, the local government often sweeps away the vendors who do not adhere to the regulation by selling their merchandise on the pavement. The vendors' activities often make the traffic jammed, and the heap of litter or garbage scatters everywhere and along the road. The existence of a market is

* Corresponding author. ORCID ID: 0000-0003-3279-5277

Peer review under responsibility of Bussecon International Academy.

(C) 2019 Bussecon International. Hosting by SSBFNET- Center for Strategic Studies in Business \& Finance. All rights reserved.

https://doi.org/10.20525/ijrbs.v8i5.456 
essentially aimed at providing services to the community to fulfill various desires needed for daily survival. But in the current development, the city of Medan is still not maximized in market management. All groups of people feel disturbed by their comfort, including the middle and lower economic class. Traditional markets should be a good public service facility so that people are comfortable shopping, even traditional markets can potentially become regional icons. This is in line with the research conducted by Dewi (Dewi, 2013) suggesting traditional market conditions physically lagging behind the modern market, due to the low level of awareness of discipline, cleanliness, and orderliness, and lack of attention to maintaining physical facilities that smell, dirty and muddy environmental conditions.

A traditional market is market which constructed and managed by the government, local government, private companies, State's owned Businesses, Regional Government's Owned businesses, including cooperation with private companies with stores, stands, and stalls. It is expected that traditional markets can be managed and developed and has high competitiveness so that they can compete with modern markets. The problem which has to be faced today is how to develop a traditional market to be healthful and clean, and can be managed professionally like a modern market because today traditional markets in Medan are managed badly, especially in their management professionalism. This problem which encouraged the writer to find out the role of stakeholders such as the Regional Government of Medan Market, Urban Civil Service Police, Sanitary Agency of Medan, vendors, buyers, and the people in its vicinity in revitalizing this traditional market.

\section{Literature Review}

\section{Governmentality}

The analysis of government according to Foucault can be done by considering the existence of three dimensions of government. First, the reason for the government, which includes all forms of knowledge, expertise, and calculations that make people think so that they agree with the political program. Second, government engineering techniques, which deal with practical mechanisms, instruments, and programs through the authority of various human behaviors. Third, the subject of government, which includes various types of individuals and collective identities that arise from and accept government activities.

Research conducted by (Hardin, 1968) issued the term "tragedy of the commons" which describes the rights that are not clear from the resource authority because resources are open access that has an impact on the destruction of resources. But now when tenure rights are getting clearer, it turns out that resource destruction is still happening. Of course, this has a close relationship with stakeholders involved with the existence of voluntary traditional markets.

\section{The Reason of government}

It is the basis of consideration that includes all forms of knowledge, expertise and calculations that can make people think as to make them agree to political programs. In this study the reason for the government to issue regulations on traditional market management is to order, orderly, safe, healthy and clean traditional markets, as a form of service to the community, driving the regional economy, and so that traditional markets can be utilized by the community as the fulfillment of needs daily. Regions are allowed to regulate and consider regional income to increase PAD. Traditional markets must be protected and must be able to compete with the modern market, but on the other hand, the regional / city governments also want to obtain PAD as much as possible as well as for the welfare of the people in their respective regions.

\section{The technic of government}

Techniques carried out by the government regarding practical mechanisms. The instrument, and program through which authorities of various types try to form and instruct humans. Techniques carried out by the government can change the implementation of public policy. According to (Dunn, 2003) government policy is intellectual and practical effectiveness aimed at creating, critically assessing and communicating knowledge about the policy process and in the policy process. In government policy, there are general procedures commonly used to solve a problem, namely problem formulation, forecasting, recommendations, monitoring, and evaluation. In line with (Sudarno Sumarto, 2007) there are several things that must be the basis for policymakers to maintain the viability of traditional markets apart from regulatory government policies, including (1) Improving traditional market facilities and infrastructure. The problem of limited funds should be overcome by collaborating with the private sector. The concept of market building even when renovation must be considered so that problems such as building concepts that are not following the wishes of the seller and the buyer and the lack of air circulation do not recur. (2) Make total improvements to market management.

\section{The subject of government}

Subjects include a variety of individual types and collective identities arising from government activities. Government subjects according to Inda (2008) include various types of self, personal, actor, agent, or identity that follow or arise from government activities. Focus on the subject can be done on two levels. First, understand how the government is closely involved in shaping modern subjects through government programs and practices. Second, observing how agents instill identity on themselves. It is noteworthy that practices in government do not always work well and perfectly shape the subject as expected, because individuals can negotiate processes related to what they are subjected to. Therefore, it is important in the study of governmentality not only to 
rely on forms of identity and individuals promoted through government practice but also to see how certain agents negotiate forms, whether they will accept, then adapt them or even reject them.

\section{Research and Methodology}

This article used descriptive qualitative method which was aimed to describe the role of stakeholders in managing the order and sanitation at Sukaramai traditional market, based on the available facts and attempted to find the truth according to the available phenomena by using descriptive qualitative design. Therefore, the writers approached the research object by digging up information according to their perception and the informants' which could develop according to the interaction in the process of interviews. The research was conducted at Sukaramai traditional market in Kelurahan Tegal Sari III, Medan Area Sub-district, Medan. Interviews were conducted with informants that consisted of government employees of the regional market company in Medan, the Sanitation and Landscape Agency of Medan, Satpol PP (Urban Civil Service Police), vendors, and buyers at the traditional market of Medan. The informants were selected according to their capacity and understanding the data and facts and according to the objective of the research. The informants who participated in this research were as follows:

Table 1: List of informants

\begin{tabular}{lll}
\hline No & Names & Position \\
\hline $\mathbf{1}$ & Azhar Daulay & Head of Gen. Dept. of Regional Market Company of Medan \\
\hline $\mathbf{2}$ & Iwan & Head of Order Dept. of Regional Market Company of Medan \\
\hline $\mathbf{3}$ & Baharuddin Harahap & Head of Waste Dept. of Sanitation and Landscape of Medan \\
\hline $\mathbf{4}$ & Zainal Arifin & $\begin{array}{l}\text { Head of Operation Sect. of Sanitation and Landscape Department of } \\
\text { Medan }\end{array}$ \\
\hline $\mathbf{5}$ & Rudi Hermansyah & $\begin{array}{l}\text { Head of Retribution Sect. of Sanitation and Landscape Department of } \\
\text { Medan }\end{array}$ \\
\hline $\mathbf{6}$ & Doni Damanik & $\begin{array}{l}\text { Head of Operation Sect. of Satpol PP Agency (Urban Civil Service } \\
\text { Police) }\end{array}$ \\
\hline $\mathbf{7}$ & Asman & Head of Gen, Dept, of Satpol PP Agency (Urban Civil Service Police) \\
\hline $\mathbf{8}$ & Nurayanti & Vegetable vendors at Sukaramai traditional market \\
\hline $\mathbf{9}$ & Riyani & Scarf vendors at Sukaramai traditional market \\
\hline $\mathbf{1 0}$ & Rosnani & Fruit vendors at Sukaramai traditional market \\
\hline $\mathbf{1 1}$ & Ujang & Fish vendors at Sukaramai traditional market \\
\hline $\mathbf{1 2}$ & Maya & Buyers at Sukaramai traditional market \\
\hline $\mathbf{1 3}$ & Sari & Buyers at Sukaramai traditional market \\
\hline $\mathbf{1 4}$ & Ulfa & Buyers at Sukaramai traditional market \\
\hline $\mathbf{S O}$ & Rear &
\end{tabular}

Source: Research Result, 2019

\section{The role of stakeholders in implementing the management policy of Sukaramai traditional market}

\section{The Reason of government}

The government's consideration, in this research, was that the Government issued the regulation on the management of traditional market according to Perda (Regional Government Regulation) No. 10/2014, participating in implementing regional development in particular and economic development, organizing public utility in the form of providing and increasing a qualified and adequate market facility for fulfilling people's needs a the profits in order to increase the contribution of Regional Businesses on PAD (Regional Generated Revenue). The role of stakeholders is ideally to carry out public service in the management of market are. In implementing its role, there are some references as follows: Perda No. 10/2014 and implementing principal job and function, the role of planning, developing, maintaining, and taking care of market area. The Market Regional Business of Medan as the Regional Government's Owned Business which controls market activities in Medan plays its role in planning how the market can run smoothly toward a better one. The data obtained from interviews with the Market Regional Business of Medan revealed that it had made a policy to create order in the region as the people's welfare. This was in accordance with the result of the research done by Fatimah and Sujadi which stated that one of the attempts to accelerate the development was by increasing PAD (Regional Generated Revenue). 
A traditional market is one of the potential sources of PAD (Regional Generated Revenue) which came from market retribution and parking and whatsoever a traditional market has its contribution to regional economic development (Nurhayati, 2014).

\section{Technique of government}

The technique done by the government is concerned with the mechanism of practical instrument and the program through which the authorities from various types attempt to establish and instrumentalize human beings. The technique done by the government can be $\mathrm{n}$ implementation of public policy which the implementation or application of a public policy through programs, activities, actions, or actions in a mechanism concerning a certain system. There are many theories presented in the policy activity. Legal provisions which existence is recognized has conclusive legal enforcement, but in practice of the government's daily implementation, a product of policy rule (bleidregel) has its own characteristics which are different from legal provisions.

\section{Planning, Maintaining, and taking care of market area}

Product of policy rule is closely related to the use of freis ermessen, a body or government official that formulates the policy in various forms such as regulations, guidelines, announcements, or circular letters to announce the policy. In accordance with its function, Market Regional Business of Medan plays its role in planning, maintaining, and taking care of market area. It has the right and obligation to do the development of markets in order to provide comfort for vendors and buyers. Taking care of markets is also focused on market sanitation and order. It has eight cleaning service personnel who start their jobs at 6:00 AM until 4:00 PM.

They sweep up the valleys in the building of Sukaramai market, its basement, the first floor and the second floor. The garbage was then carried away to the garbage dumps and carried away with garbage trucks to the landfill. In maintaining the sanitation of Sukaramai market, the regional market company of Medan works together with the Sanitation Department of Medan. The regional market company of Medan cleans up inside of the building while the Sanitation Department cleans up outside of the building such as the pavements and sidewalks surrounding Sukaramai market. In other words, sanitation is the responsibility of the regional market company of Medan.

The data obtained from the interviews revealed that the management of sanitation at Sukaramai traditional market was not maximal and the informants said that market sanitation was done every day, but the vendors threw away their garbage randomly so that the garbage scattered everywhere which made the market unorganized. Besides that, the stakeholder, in this research, did not work optimally. The sanitation employees began to feel that the garbage did not decrease so that it was difficult for them to manage it. This condition was in accordance with the result of the research done by (Sarwoko, 2008) which stated that the performance of traditional markets was far different from that of modern market, especially in sanitation and garbage dumps.

\section{Provision, Facility and Infrastructure of the market area}

The regional market company of Medan is demanded to provide facilities an infrastructure for the vendors, to maintain, and to take care of all facilities at Sukaramai traditional market. The result of the interviews showed that the provision and the maintenance of the market area was not sufficient even though the Market Regional Government of Medan has built the market building. The informants said that the market building was not strategic for the process of selling and buying - the stands were too small, the stairs to the first floor and to the second floor were too steep, the parking lot was too small, and the rest rooms were too dirty.

\section{Supervision and Handling the market area}

Besides providing the facilities and equipment for the market, the regional market company of Medan has to supervise and handle the market area which has been prepared by the government. It was found in the field that supervision and the handling of the market area has been done by the stakeholders but there are some obstacles such as the street vendors sell their merchandise on the pavements and sidewalks. However, the stakeholders should be responsible for it.

\section{Fostering the vendors at the market area}

The regional market company of Medan should provide counseling for the vendors in using the market area as properly as possible since it belongs to all of them so that its survival should be maintained. However, from the result of the interviews, it was found that counseling for vendors had not been carried out.

\section{Implementing and developing cooperation by the regional market company of Medan}

The implementation of cooperation among the parties in developing the activities concerning the market is done by the regional market company of Medan to develop the market activities and to enhance and increase the function of markets in Medan. From the result of the interviews with the head of the Operation Department and the head of the general department of the regional market company of Medan, it was found that they had the same opinion that the Sanitation and Landscape Agency was not involved as the stakeholder in the management of Sukaramai traditional market.

This is supported by the regulation on the cooperative agreement between the regional market company of Medan and the Sanitation and Landscape Agency of Medan concerning Garbage transportation and Garbage Exposure in Medan in Article 2 of the Right and the Obligation of the Second Party (the Sanitation and Landscape Agency of Medan). 
In the implementation of this cooperative agreement the Second Party had the obligation as follows :

i. Managing waste transportation and exposure from the TPS (temporary garbage dumps) in the area of the regional market company of Medan to the TPA (landfill) according to the volume of garbage which has been agreed, based on the number of markets;

ii. Providing garbage trucks and garbage containers at the TPS in the markets which have been specified by both parties and its transportation to the TPA every day punctually according to the agreed schedule;

iii. The Second Party is required to carry out the task from 7:30 AM to the completion with the number of trips coordinated with the First Party, and when there are obstacles or technical changes about the location of markets, the schedule, and the number of trips of transportation, all of them will be adjusted to the condition in the field, bed on the agreement without disregarding the substance of the agreement;

iv. Coordinating with each area coordinator in carrying out the tasks technically as it is specified in point (c) of this article is the responsibility of the Second Party.

In implementing this Agreement, the Second Party is required to

i. Receive the fee in the form of money for transporting the waste ordered by the First Party as it is specified in Article 5, paragraph 1 of this Agreement;

ii. Receive the fee in the form of money for servicing waste exposure ordered by the First Party as it is specified in Article 5, paragraph 2 of this Agreement.

Article 3 on the Right and Obligation of the First Party

i. The first Party in this Cooperative Agreement is required to:

a. Pay the service for waste transportation and exposure from TPS to TPA which is carried out by the Second Party as it is specified in Article 5, paragraph 1 of this Agreement;

b. Pay the service for waste exposure at the TPA carried away or transported by the Second Party from TPS to TPA as it is specified in Article 5, paragraph 2 of this Agreement.

Place or collect the market waste to TPS or to Garbage containers before it transported by the Second Party.

i. The First Party in this Cooperative Agreement is required to:

a. Receive waste containers at the TPS at the markets specified by both Parties and they are transported every day and at any time;

b. The First Party had the right to transport the garbage from TPS at the markets which do not get services in waste transportation to TPA from the Sanitation and Landscape Agency of Medan.

\section{Subject of government}

The subject includes various individual types and collective identity aroused from the government's activities. The government's subject according to (Inda, 2008) includes various types of self, personality, actors, agents, or identities which are followed or come from the government's activities. The focus on the subject can be done in two levels. First, understanding how the government is closely involved in establishing modern subjects through the government's programs and practices. Secondly, observing how the agents instill identity in themselves. It is worthwhile to notice that practices in the government are not always successful well and completely in establishing subjects according to what has been expected because individuals can negotiate the processes related to what is subjected. Therefore, it is important in the governmentality study to not only depends on the forms of identify and individuals that are promoted through the government's practices but also finds out how certain agents negotiate the forms whether they receive and adjust or refuse them.

The data revealed that the vendors prefer sell their merchandise on the pavement of Sukaramai because of some factors such as to get more maximal earnings. If they sell their merchandise inside the market building, there will be a few buyers who buy their goods, and they will be short of earnings. Although the Satpol PP often do the sweeping, the vendors seem not to obey and comeback to the Sukaramai pavement to sell their goods. This is in accordance with the research done by Taufik (2003) which analyzed the resistance of the Minangkabau street vendors in Yogyakarta against the government's policy on their existence as street vendors. Taufik pointed out that the resistance against the government was non-violent. This was based on their cognitive and knowledge which was based on their proverbs and doctrines as the Minangkabaunese. They tried hard not to resist violently and avoid violent action. They believe that violent or physical action is only done by animals and it will not settle the problems and even complicate the problems. They pay homage to the authorities when the latter symbolizes justice and welfare when this does not occur, they will be reluctant to and 
reject the government's order or even mock the government, and this will be done silently. They will explicitly obey the government but implicitly resists it.

Meanwhile, the buyers gave their opinion that they like to shop on the pavement because the price was cheaper; besides that, they can choose variety of goods to buy although they have to be careful since the traffic was hectic. They also believed that the building was not safe enough for them since the stairs were steep and the alleys were too narrow.

\section{Analysis on the role of stakeholders in implementing the management policy of Sukaramai traditional market}

There are still many traditional markets in Medan which are not clean and organized well. A market is identical with congestion, filthy, and unorganized except modern market such as malls or department stores. So far, Sukaramai market has categorized as dirty because waste was scattered around the market area. Even though the waste is carried away every morning and afternoon, only a few of the traditional markets in Medan are organized well.

Waste management is not maximal. Sukaramai market is also known as an unorganized market in Medan. Although the waste is carried away every day, its sanitation is not good.

The problem of waste undergone by the vendors should be handled seriously by the government because garbage is a nuisance for selling and buying activities. According to the vendors, the waste scattered around the market came from the vendors who sold vegetables and fish that it causes bad smell and made the buyers uncomfortable. Retribution for waste management from the vendors was collected IDR 2,000 every day. It is intended to clean up the waste done by the waste workers to be collected, but they only throw it away to the heap in front of the shop houses and will be carried in the next day to the landfill. Street sweepers clean up the alleys in front of shop houses and the pavement and carry the waste which has been put in front of the shop houses. The waste will be taken away from the TPS (temporary garbage dumps) and transported to the TPA (landfill).

The market facility is also not good. The stairs are too steep so that the buyers are very reluctant to enter the market building; the stands are very small so that it is very difficult for the vendors to put their merchandise which is different from the place on the pavement where they can load their stands since the area is wide. This condition is an accordance with the research conducted by Wahyudi \& Yuniman (2006) which states that the existence of traditional markets has become an alarm by the appearance of modern markets. Undeniably, the decline of traditional markets is caused by their bad condition such as lack of facility and infrastructure, their density is unbearable with the merchandise which scattered to the sidewalk, their corridors are very narrow, very crowded, and very filthy. All these things are very contrary to the comfortable condition of modern markets.

The government should provide shelter for vendors by giving them capital, comfortable stands which are affordable. It has to be firm in asking the vendors to sell their merchandise inside the market building provided by the government. Actually, the government has provided stands inside the building with high price so that the vendors cannot afford to buy them since there is unbalanced between the capital and the earnings; only rich vendors who can buy the stands inside the building. It seems that the government cannot force the vendors to sell their merchandise inside the building. This is in accordance with the research conducted by Hardin (1968) entitled, Tragedy of Commons, which describes the uncertainty of the right of the authorities, and when their rights becomes distinct or certain, the damage in resources always occurs.

The buyers' characteristics in Medan are typically simple in shopping. They are reluctant to enter the market building since its position is not good. It seems that there is no order in the vendors who sell their merchandise on the side of the road; it is very crowded and full of vendors and road users. Of course, sweeping is done every day by the government but the vendors seem not to succumb since they have to survive in supporting their families. In consequence, they have to play cat and mouse with the Satpol PP (Urban Civil Service Police). The government should provide counseling for the vendors so that they will be in order; unfortunately, there has not been counseling so far.

The existence of traditional markets should be paid serious attention in the rapid urban development. The lifestyle of traditional markets is closely related to simple lifestyle and socialization. The relationship among the vendors is very good and full of tolerance, helping to each other; they talk and chat to each other. Relationship between vendors and buyers is very specific. Usually the vendors have intimate customers, and it seems that they trust to each other. The hubbub of bargaining becomes the spirit of market. This condition makes it different from the condition of a modern market. The relationship between vendors and buyers in a modern market is not interpersonal; there is no social interaction between them; the buyers will automatically go after they have bought something.

The finding in the field about the role of Stakeholders in the implementation of the policy on managing Sukaramai traditional market showed that not all stakeholders played the role on managing traditional markets. The regional market company of Medan and Satpol $P P$ (Urban Civil Service Police) of Medan have made their policy according to the prevailing legal provisions. These two stakeholders play their role in the implementation of sanitation and order at Sukaramai Traditional Market. However, the Sanitation Department is not involved in its management because it only cleans up the road side or sidewalk around the Sukaramai Market and is not involved in waste management inside the market. 
The implementation of the policy on managing traditional markets has been dined by imposing the prevailing regulations. This is in accordance with the theory used in this research, the theory of governmentality by Foucault which is called as conduct of conduct which means the State regulates people's actions or behavior the internalizing obedience in order that people become obedient. The existence of the Reason of Government, Perda (Local Regulation) No. 10/2014 as the basic consideration of the Government, the existence of Technique of Government as the method in implementing the policy, and the existence of Subject of Government as the persons who implement the policy. However, in its practice in the field, there are some obstacles in implementing the policy such as the sweeping of street vendors who sell their merchandise on the pavement. As an agency, the government has the authority and responsibility which have to be accomplished such as market management and market operational implementation. In handling sanitation, the local government has provided eight cleaning service workers and a Market Head, an in maintaining order, the local government has provided Satpol PP (Urban Civil Service Police), especially for putting street vendors into order.

The policy in managing market activity is still subjective in which the vendors are not involved. The policy is only made and decided by the local government which is then socialized to vendors through circular letters. Fostering vendors has not been implemented by the government. From the available facility and infrastructure in this market, it can be concluded that the condition of the market is not optimal. The reasons are the market area is too small and the stands are also too small.

The implementation of putting street vendors into order was done persuasively to minimizing the clash in the field. When this attempt fails, Satpol PP (Urban Civil Service Police) will handle it by confiscating the merchandise of the street vendors who sell their merchandise on the pavement and the roadside, but the action should be command because they cannot do it by their own wish.

\section{Conclusions}

There are some factors which caused Sukaramai traditional Market to be filthy, unorganized, stink, and disordered. First, it was case by the noncompliance of the vendors with doing their selling activities. They were focusing on getting earnings quickly by selling their merchandise on the pavement. It was because the buyers were reluctant to enter the market which was muddy and stinks so that they decided to shop on the pavement. Secondly, the market building was not strategic and not supporting the process of buying and selling: the alleys were too narrow, the stands were too small, the stairs to the first floor and to the second floor were too steep, the parking lot was too small, and the rest rooms were too dirty. Besides that, the leasing price was high so that the vendors could not afford to rent them. Thirdly, the Stakeholders did not work optimally in managing Sukaramai Traditional Market - the Sanitation Department did not do its duty to handle waste management in this market so that it was muddy and stink. The government must care to protect traditional markets that are still needed by the community, especially the lower middle class and also people in the periphery. The existence of traditional markets must also get more serious attention from the government. Government's partisanship in this matter is important, considering that market assets are owned by the government and traders only hold usage rights. The government must protect the market as an integrated effort to build sustainable market resilience and be able to empower the market as a space for economic activity to achieve the welfare of the community. Therefore, the Government should prepare a strategic and feasible market for traders so that the Sukaramai Traditional Market stewardship can run well. Besides, the Government must make a strict ban by not allowing traders who sell goods on the road Sukaramai to avoid market clutter.

\section{References}

Dunn, W. N. (2003). Analisis Kebijakan Publik. Yogyakarta: Gajahmada University Press.

Dewi, R. S. (2013). Pengaruh Faktor Modal Psikologis, Karakteristik Entrepreneur, Inovasi, Manajemen Sumber Daya Manusia, dan Karakteristik UKM Terhadap Perkembangan Usaha Pedagang di Pasar Tradisional (Studi kasus pada Pedagang Sembako dan Snack di Pasar Peterongan). Jurnal Administrasi Bisnis Undip. 2 (1). https://doi.org/10.14710/jab.v2i1.5352

Febrianty, D. (2013). Model of Role Strengthening of Traditional Market. Journal of Economics and Sustainable Development, 4(5), 115-124.

Hardin, G. (1968). The tragedy of commons. Science. 162 (3859), 1243-1248. DOI: 10.1126/science.162.3859.1243

Inda, J. X. (2008). Anthropologies of Modernity: Foucault, Governmentality, and Life Politics. In Anthropologies of Modernity: Foucault, Governmentality, and Life Politics. https://doi.org/10.1002/9780470775875

Nelwan, J. W., Lapian, J., \& Rumokoy, F. (2017). The Existence Of Traditional Market Toward Modern Market In Tomohon City. Jurnal EMBA, 5(3), 3348-3355.

Nurhayati, S. F. (2014). Pengelolaan Pasar Tradisional Berbasis Musyawarah Untuk Mufakat. BENEFIT Jurnal Manajemen Dan Bisnis, 18(1), 49-56. DOI: 10.23917/benefit.v18i1.1387

Prastyawan, A., \& Isbandono, P. (2018). The role of local governments in traditional market revitalization. Journal of Physics: Conference Series, 953(1). https://doi.org/10.1088/1742-6596/953/1/012164

Sarwoko, E. (2008). Dampak Modernisasi Keberadaan Pasar Modern terhadap Pedagang Pasar Tradisional di Wilayah Kabupaten $\begin{array}{lllllll}\text { Malang. Jurnal } & \text { Ekonomi } & \text { Modernisasi. } & 4 & \text { (2), } & 97-115 . & \text { Retrieved from }\end{array}$ http://ejournal.unikama.ac.id/index.php/JEKO/article/view/880

Sudarno Sumarto, A. S. (2007). Pasar Tradisional di Era Persaingan Global. Jakarta: SMERU Research Institute. Retrieved from SMERU (Lembaga Penelitian SMERU). 
Tanuwidjaja, G., \& Wirawan, R. (2012). Creative - Sustainable Traditional Market Design in Malang. The 2nd International Conference Planning in the Era of Uncertainty: Sustainable Development.

Taufik, M. (2003). Perlawanan Pedagang Kaki Lima Minangkabau Jogjakarta Terhadap Peraturan Daerah. Yogyakarta: Universitas Gadjah Mada.

Wahjudy, M. d., \& Yuniman, A. (2006). Analisa perkembangan pasar tradisional (studi komparatif terhadap pengguna ruang komersial di pasar Atum, pasar Turi, pasar Wonokromo). Surabaya: Bachelor thesis, Petra Christian University. 